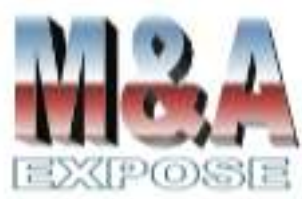

http://jurnal.usahid.ac.id/index .php/accounting
${ }^{1}$ Fakultas Ekonomi

Universitas Darma Persada srekosaprianto@qmail.com

${ }^{2}$ Fakultas Ekonomi
Universitas Bung Karno
Jakarta
${ }^{3}$ Fakultas Ekonomi
Universitas Widya Dharma
Klaten
${ }^{4}$ Fakultas Ekonomi
Universitas Sahid Jakarta

\section{Metode Balance Score Card dalam Peningkatan Efektivitas dan Efisiensi untuk Menghadapi Persaingan Bisnis}

\author{
Reko Saprianto ${ }^{1}$, Jefri Lukito ${ }^{2}$, Titik Purwanti ${ }^{3}$, \\ Endang Wulandari ${ }^{4}$
}

\section{Abstrak}

Balance score card yang diperkenalkan Norton dan Kaplan pada tahun 1992 membawa angin segar ke perusahaan atau organisasi bisnis untuk diterapkan untuk mencapai hasil yang diinginkan dan diharapkan dalam pencapaian tujuan, target, dan kinerja. Penerapan balance score card akan mengarah pada efisiensi dan efektifitas pencapaian visi dan strategi sehingga kepekaan bisnis terhadap lingkungan dapat tercapai. Dengan demikian kualitas, layanan, kreativitas, inovasi dan keunggulan kompetitif dapat tercipta. Oleh karena itu, balance score card harus diterapkan secara konsisten, focus, dan meningkat berkelanjutan.

Kata kunci : balance score card, efektivitas, efisiensi, persaingan bisnis.

\section{Abstract}

Balance score card which was introduced by Norton and Kaplan in 1992 bring a fresh breeze to the company or business organsisasi to be applied to achieve the desired results and would be expected as achieving objectives, targets, and performance. The application of the balance score card will lead to efficiency and effectiveness in achieving the vision and strategy so that business sensitivity to the environment can be achieved. Thus quality, service, creativity, innovation and competitive advantage can be created. Therefore, the balance score card must be applied consistently, focused, and continually increased.

Keywords : balance score card, effectivity, efficiency, business competitive. 


\section{PENDAHULUAN}

Era globalisasi membawa perubahan luar biasa pada seluruh nilai aspek kehidupan manusia yang dapat memberikan pengaruh baik secara langsung maupun tidak langsung. Pengaruh tersebut bukan hanya pada nilai aspek manusia namun juga menyentuh pada nilai aspek sendi kehidupan perusahaan atau organisasi bisnis, baik yang bergerak di bidang jasa maupun industri. Fenomena ini tentu saja mempengaruhi eksistensi organisasi bisnis itu sendiri.

Itulah sebabnya perusahaan membutuhkan upaya serius dalam menjalankan dan mempertahankan perusahaan, serta lebih dalam lagi upaya untuk menumbuhkembangkan nilai perusahaan. Upaya tersebut diperlukan untuk menghadapi gelombang perubahan yang disebabkan dinamisnya lingkungan bisnis dan globalisasi. Dalam menghadapi hal tersebut, maka organisasi bisnis membutuhkan keseriusan, fokus dan analisis cermat dalam mengelola organisasi, mengembangkan, dan mempertahankan organisasi. Dengan demikian diharapkan organisasi bisnis memiliki nilai fundamental yang kuat, yang bukan hanya berorientasi pada keuntungan semata namun juga berdasarkan efektivitas dan efisiensi. Hal ini sangat diperlukan dalam menghadapi perubahan lingkungan bisnis dan pencapaian visi organisasi. Oleh sebab itu, dibutuhkan komitmen kuat yang dibangun dengan seluruh komponen sumber daya organisasi dan sumber daya manusia. Selain itu juga dibutuhkan interaksi dan koordinasi dari berbagai fungsi bisnis yang berperan dalam organisasi bisnis.

Peran kepemimpinan juga dibutuhkan dalam organisasi sebagai jiwa dalam organisasi bisnis untuk melakukan perubahan dan menjadi pioneer dalam perubahan. Kepemimpinan diharapkan dapat memunculkan agen perubahan dalam organisasi sehingga dapat mewujudkan efektivitas dan efisiensi dalam menghadapi persaingan bisnis yang semakin ketat. Namun hal tersebut juga perlu didukung penerapan sistem dan metode yang tepat agar gerak organisasi bisnis yang dinamis dapat berjalan dengan baik sesuai dengan harapan bersama.

Metode Balance Score Card merupakan salah satu metode yang sangat baik untuk diterapkan atau diaplikasikan dalam organisasi untuk mewujudkan efektivitas dan efisiensi dalam lingkungan persaingan bisnis. Selain itu, metode tersebut juga akan mendukung pencapaian visi dan kemampuan beradaptasi di tengah persaingan yang semakin ketat. Atas dasar inilah maka diperlukan analisis situasi berdasarkan metode Balance Score Card untuk dapat diaplikasikan pada organisasi bisnis.

\section{TINJAUAN PUSTAKA}

Balance Score Card pertama kali diperkenalkan oleh Bob Kaplan dalam sebuah artikel di Harvard Business Review pada tahun 1992. Sejak saat itu, lebih dari 200 perusahaan di Amerika Serikat tertarik untuk menerapkan metode Balance Score Card untuk memajukan organisasi bisnis atau perusahaan. Agar dapat menerapkan akan Balance Score Card secara optimal, maka perusahaan harus lebih memahami makna strategi.

Strategi bukan hanya dalam makna sempit, semata-mata tujuan pemimpin perusahaan saja. Strategi harus menjadi bagian dari keseluruhan organisasi bisnis. Ruh dan jiwa strategi harus berada dalam jantung kepemimpinan dan tertanam dalam nilai-nilai bisnis yang kuat. Dengan demikian strategi dapat menjadi nilai inti yang kuat yang dijadikan fundamental organisasi bisnis, yang diwujudkan dalam langkah nyata dalam upaya memenangkan persaingan. Strategi memiliki peran sangat penting dalam perusahaan karena menjadi sarana pencapaian tujuan perusahaan. Oleh sebab itu, strategi harus dikomunikasikan pemimpin perusahaan pada seluruh anggota perusahaan agar dapat dipahami dan mengakar kuat dalam tiap tindakan dan langkah nyata manajerial. 
Jadi Balance Score Card membantu perusahaan dalam mewujudkan strategi secara keseluruhan dalam setiap elemen bisnis dan bukan secara parsial, sehingga menjadi kekuatan perusahaan. Hal ini merupakan suatu metode yang dapat diaplikasikan dalam perusahaan dengan cara, format, dan nilai yang benar sehingga akan berdampak positif pada bisnis yang dijalankan pada perusahaanbaik yang bergerak di bidang industri maupun jasa.

Atas dasar inilah maka berbagai bentuk penghambat bisnis harus dihilangkan, selain itu prasangka dan apriori negatif terhadap Balance Score Card harus disingkirkan. Pencapaian tujuan bisnis perusahaan tidak terjadi seketika, namun membutuhkan upaya, ketekunan, dan komitmen kuat yang dibangun dengan tindakan berkesinambungan untuk menerapkan metode Balance Score Card. Selain itu juga harus membangun mental yang kuat serta perilaku yang produktif dalam organisasi bisnis. Tak kalah pentingnya adalah keberadaan ikatan kuat, kerja sama, koordinasi, dan interaksi yang dibangun dalam setiap fungsi bisnis. Semua komponen tersebut harus ditunjang dengan sudut pandang yang benar dan niat yang kuat dalam mengaplikasikan metode Balance Score Card dalam mewujudkan efektivitas dan efisiensi di tengah iklim persaingan yang ketat.

\section{METODE}

Menurut Gaspersz (2006), Balance Score Card merupakan sebuah metode yang berdasarkan visi dan strategi organisasi bisnis serta dikaitkan dalam empat perspektif yaitu :

1. Persepktif keuangan.

2. Perspektif pelanggan.

3. Perspektif proses bisnis internal.

4. Perspektif pembelajaran dan pertumbuhan karyawan, manajemen dan organisasi.

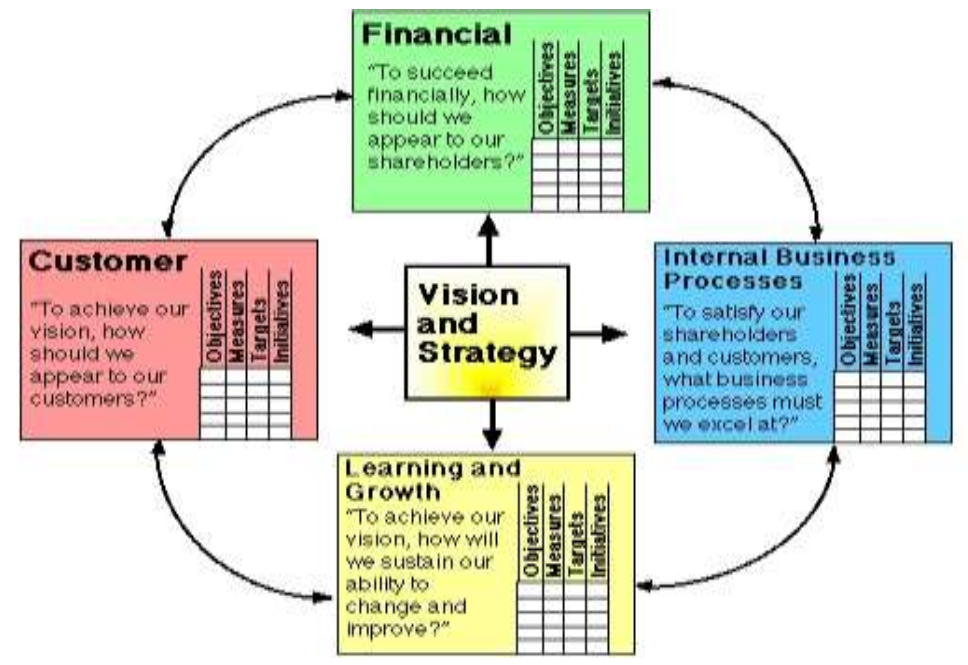

\section{PEMBAHASAN}

Visi dan strategi perusahaan secara seimbang harus menjadi nilai organisasi dan diwujudkan dalam tindakan nyata yang diaplikasikan. Pemimpin perusahaan harus mengkomunikasikan strategi dalam tindakan nyata berdasarkan perspektif keuangan, perspektif pelanggan, perspektif proses bisnis internal, serta perspektif pembelajaran dan pertumbuhan karyawan, manajemen dan organisasi. Metode ini juga harus ditanamkan dalam perusahaan agar terwujud dalam pengetahuan, keterampilan dan sistem yang 
memungkinkan karyawan dan manajemen berkembang dan mencapai hasil yang optimal sesuai nilai harapan yang ingin dicapai.

Terdapat empat faktor penghambat dalam implementasi bisnis strategi agar nilai-nilai perspektif tersebut dapat dartikan secara tepat (Evans, 2002), yaitu :

1. Hambatan visi,

Tidak banyak orang dalam organisasi yang memiliki pemahaman strategi organisi bisnis. Berdasarkan survei, hanya sekitar 5\% karyawan yang memahami strategi organisasi bisnis di tempatnya bekerja.

2. Hambatan orang,

Banyak orang dalam organisasi memiliki tujuan yang tidak terkait dengan strategi organisasi. Berdasarkan survei, hanya sekitar $25 \%$ dari manajer yang memiliki insentif terkait dengan strategi perusahaan mereka.

3. Hambatan sumber daya,

Waktu, energi, dan uang tidak dialokasikan pada hal-hal yang penting sehingga menghasilkan pemborosan sumber daya. Sekitar $60 \%$ organisasi tidak mengkaitkan anggarannya dengan strategi perusahaan.

4. Hambatan manajemen,

Manajemen menghabiskan waktu atau terlalu sedikit waktu untuk strategi, sebaliknya terlalu banyak waktu untuk keputusan taktis jangka pendek. Berdasarkan survei, sekitar 86\% tim eksekutif menghabiskan waktu kurang dari satu jam per bulan untuk mendiskusikan strategi mereka.

Metode untuk menghilangkan hambatan yang salah dan membangun nilai-nilai yang tepat dalam penerapan Balance Score Card, yaitu :

1. Visi adalah suatu pernyataan menyeluruh tentang gambaran ideal yang ingin dicapai oleh organisasi di masa datang yang diciptakan melalui konsensus, pencitraan ideal di masa yang akan datang yang mempengaruhi mental orang agar berhasrat mencapainya, menggambarkan sesuatu yang mungkin, tidak perlu harus diperkirakan, memberikan arah dan fokus, mempemgaruhi orang untuk menuju ke visi tersebut, dan tidak memiliki batas waktu.

2. Misi adalah suatu pernyataan bisnis dari organisasi bisnis yang menyatakan alasanalasan keberadaan organisasi, tidak menyatakan suatu hasil, tidak ada batas waktu pengukuran, memberikan basis pembuatan keputusan tentang alokasi sumber-sumber daya dan penetapan tujuan yang tepat, mendefinisikan bisnis sekarang dan yang akan datang dalam bentuk produk, skor, pelanggan, alasan-alasan, dan pasar.

3. Sasaran adalah suatu pencapaian menyeluruh yang dipertimbangkan penting untuk kesuksesan organisasi bisnis di masa mendatang. Sasaran menyatakan organisasi ingin berada di masa mendatang dengan menggambarkan keadaan ideal yang ingin dicapai beberapa waktu mendatang di mana waktu mendatang dapat atau tidak perlu diidentifikasi secara pasti, konsisten terdefinisi secara berkaitan secara langsung dengan visi dan misi, memberikan petunjuk untuk pembuatan keputusan dan tindakan seharihari, tidak perlu berkaitan dengan hasil-hasil yang dapat diukur.

4. Tujuan menunjukkan bagaimana tindakan dan hasil yang diinginkan itu tercapai dan menunjukkan rencana untuk mencapai hasil yang diinginkan. Tujuan merupakan hal-hal apa yang secara spesifik harus dikerjakan untuk melaksanakan strategi dan hal-hal yang harus dilakukan organisasi dalam strategi organisasi bisnis untuk berfokus pada isu-isu organisasi dan merupakan terobosan organisasi bisnis, menggambarkan aktivitasaktivitas yang diselesaikan untuk mencapai sasaran, mengidentifikasikan waktu spesifik, kapan dan hasil-hasil itu akan terjadi, dapat diukur dalam bentuk pencapaian hasil, dapat diukur pencapaiannya, dapat diubah apabila perlu untuk kemajuan menuju sasaran yang telah ditetapkan.

5. Pespektif adalah pandangan berbeda yang mengendalikan organisasi bisnis. Perspektif memberikan suatu kerangka kerja untuk pengukuran. Empat perspektif dalam Balance 
Score Card merupakan satu kesatuan nilai yang harus mendapat perhatian dan porsi yang seimbang dan tidak boleh salah satu terabaikan.

6. Hubungan sebab akibat adalah aliran kinerja bisnis dari tingkat lebih rendah ke tingkat yang lebih tinggi di dalam atau di antara perspektif. Hal ini menunjukkan bahwa dalam melakukan sesuatu harus memikirkan hasil atau akibat pada yang lain, oleh karena itulah maka dibutuhkan kecermatan, analisa yang tepat dan pertimbangan yang jitu.

7. Pengukuran adalah suatu cara memantau dan menelusuri kemajuan tujuan-tujuan strategis. Pengukuran dapat berupa indikator yang memimpin kinerja dan memimpin menuju hasil akhir.

8. Target adalah suatu tingkatan kinerja yang diharapkan atau peningkatan yang diperlukan di masa mendatang.

9. Program adalah inisaitif-inisiatif atau proyek-proyek utama yang harus dilaksanakan agar memenuhi satu atau lebih tujuan-tujuan strategis.

10. Pemikiran strategis adalah suatu proses intuitif dan alamiah berpikir untuk melihat sesuatu melalui kompetensi, mengantisipasi kecenderungan masa depan dan secara komperehensif memikirkan perubahan-perubahan yang dibutuhkan untuk menghadapi tantangan di masa depan. Pemikiran strategis dapat diterapkan pada individu maupun organisasi.

11. Perencanaan strategis adalah suatu pendekatan formal yang terstruktur dalam pencarian kembali dan analisis tentang kompetisi sebagai suatu usaha untuk mengidentifikasi kekuatan-kekuatan, kelemahan-kelemahan, kesempatan-kesempatan dan rancangan-rancangan atau ancaman-ancaman (SWOT Analysis).

12. Kisi strategis adalah suatu kerangka kerja logis untuk mengorganisasikan sekumpulan tujuan strategis ke dalam empat perspektif dalam Balance Score Card. Segala sesuatu dikaitkan untuk membangun sebab akibat. Kisi strategis merupakan landasan untuk membangun Balance Score Card.

13. Area strategis adalah tujuan strategis utama untuk organisasi dengan memaksimumkan nilai organisasi, efisiensi, efektivitas dalam suatu model untuk mengelola area strategis.

14. Templates adalah alat-alat visual untuk membantu dalam membangun Balance Score Card, secara tipikal digunakan untuk memperoleh dan membandingkan data dalam keempat komponen Balance Score Card.

Selain itu Balance Score Card dapat membantu menerjemahkan strategi. Balance Score Card merupakan lebih dari sekedar suatu sistem pengukuran operasional dan taktis. Perusahaan-perusahaan yang inovatif menggunakan Balance Score Card untuk melaksanakan dan menggunakan sistem manajemen strategis yang mengelola strategi perusahaan sepanjang waktu. Perusahaan-perusahaan inovatif itu menggunakan fokus pengukuran Balance Score Card untuk melaksanakan proses manajemen kritis dengan mengklarifikasikan visi dan srategi perusahaan, mengkomunikasikan dan mengkaitkan tujuan-tujuan strategis dengan ukuran-ukuran kinerja, merencanakan, menetapkan dan menyelaraskan inisiatif-inisiatif strategis, mengembangkan umpan balik dan pembelajaran strategis untuk peningkatan berkesinambungan di masa mendatang.

Proses penerapan Balance Score Card dalam organisasi akan menghasilkan kinerja dan pengukuran yang diharapkan untuk mengetahui kondisi perusahaan (Mulyadi, 2000). Hal ini dapat dilakukan dengan menggunakan SWOT Analysis yang terdiri dari :

1. Strengths (kekuatan),

yang artinya melihat dari dalam perusahaan itu sendiri mengenai kondisi internal yang menjadi nilai kekuatan perusahaan sehingga mampu menghasilkan dan mencapai akan sebuah nilai, hasil ataupun target, tujuan yang diharapkan, seperti melihat setiap komponen fungsi bisnis, departemen, unit kerja, budaya kerja, peranan CEO, karyawaan, koordinasi, interaksi serta metode dan model, sumber daya yang digunakan, nilai kompetensi yang dibangun, dan lain sebagainya. 


\section{Weakness (kelemahan),}

yang mempertanyakan apakah masih terdapat potensi kekurangan dalam organisasi atau perusahaan dalam menjalankan roda bisnisnya baik itu ketidakmampuan pemimpin dalam menanamkan budaya organisasi yang kuat, terjadi pemborosan, ketidakefektifan dalam bekerja, kesalahan dalam penerapan model bisnis, metode dan prosedur yang baik, ketidaktersediaan sumber daya yang handal, strategi yang tidak dapat diterjemahkan dalam tindakan karena tidak dipahami dan nilai kekuatan organisasi tidak dibangun dengan baik, dan lain sebagainya.

3. Opportunities (kesempatan),

artinya masih terdapatkah peluang, segmen dan pangsa pasar yang diraih untuk meningkatkan kinerja, meraih penjualan, mendapatkan keuntungan yang terlebih dahulu harus membangun kekuatan dari dalam organisasi dan memiliki kepekaan terhadap perubahan dan gerak dinamis dari lingkungan bisnis yang dapat mempengaruhi nilai kehidupan organisasi bisnis atau perusahaan itu sendiri.

4. Threats (ancaman),

artinya bila kelemahan tidak bisa diatasi dengan baik maka ancaman akan mengintai perusahaan atau organisasi bisnis yang mengakibatkan hilangkan pangsa pasar, direbutnya nilai penjualan, berkurangnya nilai keuntungan serta ketidakmampuan dalam menghadapi persaingan bisnis.

Setelah melakukan kajian SWOT, maka nilai perspektif akan dibangun dari sudut pandang Balance Score Card, yang diuraikan lebih lanjut dalam penjelasannya sebagai berikut (Gaspersz, 2005) :

1. Perspektif pelanggan.

Berbicara mengenai persepektif pelanggan berarti membangun dan mengetahui dari nilai sudut pandang pelanggan atau konsumen terhadap suatu reaksi atau respon yang berkenaan terhadap kepuasan pelanggan terhadap penggunaan nilai produk dan kemampuan dalam memenuhi bahkan melebihi nilai harapan dari pelanggan ketika telah mengorbankan sejumlah biaya untuk menggunakan produk yang dihasilkan. Maka atas dasar inilah penting untuk mengetahui fokus konsumen yang dituju untuk melakukan positioning, targeting, segmenting, serta mengetahui perilaku konsumen, life style, income dan lain sebagainya mengenai akan dimensi konsumen (Mulyadi, 2007).

2. Perspektif proses bisnis internal.

Berbicara mengenai proses bisnis internal berarti menelaah dan mencermati model, prosedur dan sistem yang dilaksanakan dan dijalankan dalam menjalankan kegiatan bisnis untuk menghasilkan suatu produk. Dalam hal ini perlu kecermatan dan ketepatan dalam menelaah proses bisnis internal yang dibangun dengan mempertimbangkan sumber-sumber organisasi dengan melihat unsur sumber daya manusia, modal, teknologi yang digunakan, informasi yang tersedia, metoda yang tepat yang dibangun yang sesuai dengan nilai inti organsasi yang dibangun dan selain itu harus memperhatikan nilai inovasi, operasional, pelayanan dan kualitas yang dibangun.

3. Perspektif pembelajaran dan pertumbuhan.

Perspektif ini bermakna bahwa dalam bisnis jangan pernah puas terhadap nilai target, tujuan dicapai baik dalam jangka pendek maupun panjang. Atas dasar inilah maka kepekaan terhadap lingkungan bisnis eksternal dan internal yang dibangun oleh perusahaan memerlukan peningkatan kompetensi dengan terus membangun kekuatan kompetensi dan nilai inti organisasi yang terarah pada peningkatan sumber daya manusia. Keterlibatan peran kepemimpinan akan menghidupkan fungsi operasional sumber daya manusia yang terarah. Hal ini dapat dilakukan dengan pelatihan, pengembangan, management talent, coaching, membangun kompetensi, membangun infrastruktur yang baik, membangun budaya yang kuat sehingga dapat melahirkan terobosan kinerja, kreatifitas, inovasi dalam bekerja yang mengarah pada pencapaian tujuan, target dan akan tercipta efisiensi, efektifitas serta keunggulan dalam daya saing. 
4. Perspektif keuangan.

Perspektif ini membahas kekuatan keuangan yang dibangun dengan memperhatikan akan unit bisnis yang dijalankan dan hal ini didasarkan pada pengukuran secara keuangan dan pencapaian nilai secara keuangan. Misalkan menganalisis profitabilitas yang mengukur efektifitas manajemen yang ditunjukkan melalui laba baik keuntungan kotor, bersih, tingkat pengembalian aset, tingkat pengembalian modal sendiri. Adapun rasio aktivitas mempertimbangkan tingkat perputaran piutang dagang, periode penagih rata-rata tingkat perputaran inventori, tingkat perputaran harta total serta mempertimbangkan rasio hutang dengan melihat hutang terhadap kekayaan bersih, hutang jangka pendek terhadap total hutang/kewajiban dan juga memperhatikan rasio likuiditas dengan melihat rasio lancer dan rasio cepat.

Perusahaan yang menerapkan Balance Score Card harus mengkaitkan dengan strategi dan visi perusahaan, maka harus dilihat visi yang dapat diterjemahkan ke dalam tindakan nyata dan mengkomunikasikan strategi ke dalam tindakan untuk memenangkan persaingan dan juga mengkomunikasikan dalam proses internal bisnis dengan penetapan target, tujuan dan kurun waktu jangka panjang dan pendek dengan memberikan peningkatan secara progresif secara terus menerus dengan penggunaan pengukuran kuantitatif seperti pencapaian tujuan, visi, pencapaian kepuasan pelanggan. Selain itu juga dengan pengukuran kuantitatif dari sisi penjualan dan keuangan dengan menggunakan berbagai pendekatan rasio keuangan yang dapat dipercaya, bersifat valid, akurat dan tepat serta adanya tindakan korektif untuk melakukan proses perbaikan tanpa mengabaikan efisiensi, efektivitas, kualitas yang dicapai serta keunggulan daya saing yang diciptakan serta kepekaan terhadap inovasi dan kreatfitas produk dan pelayanan yang diberikan serta adanya program perbaikkan bersifat berkesinambungan secara terus menerus.

\section{KESIMPULAN}

Bahwa Balance Score Card merupakan sebuah metode yang dapat digunakan oleh perusahaan atau organisasi bisnis untuk meningkatkan kinerja dan menyeimbangkan visi dan strategi organisasi yang bersifat secara terus menerus. Hal ini perlu dilakukan secara terus menerus untuk mendapatkan hasil yang diharapkan sesuai dengan harapan dan nilai yang dibangun dalam perusahaan atau organisasi bisnis.

Namun yang perlu diingat bahwa dalam penerapan metode Balance Score Card tidak bisa sekejap diterapkan namun membutuhkan upaya, daya, komitmen dan kerja sama yang perlu dibangun oleh seluruh elemen organisasi yang bersifat berkesinambungan tidak berhenti pada satu titik melainkan melanjutkan dan meneruskan dengan mempertimbangkan faktor internal dan eksternal pada lingkungan bisnis. Bila ini dilakukan dengan konsisten maka hasilnya akan didapat sesuai dengan pencapaian akan target, tujuan visi, peningkatan akan pelayanan, kualitas dan kinerja.

\section{DAFTAR PUSTAKA}

Becker B. E, et all. 2009. Human Resources Score Card. USA : Harvard Business School. Gaspersz V. 2006. Sistem Manajemen Kinerja Terintegrasi Balance Score Card Dengan Six Sigma Untuk Organisasi Bisnis dan Pemerintah. Jakarta : Gramedia Pustaka Utama.

Gaspersz V. 2006. Total Quality Management. Jakarta : Gramedia Pustaka Utama.

Gaspersz V. 2012. All In One Practical Management Excellence. Bogor : Vinchristo Publication.

Gaspersz V. 2007. Organizational Excellence Model Menuju World Class Quality Company. Jakarta : Gramedia Pustaka Utama.

Mulyadi. 2007. Sistem Terpadu Pengelolaan Kinerja Personal Berbasis Balance Score Card. Yogyakarta : Sekolah Tinggi Ilmu Manajemen YKPN. 